\title{
Moral Conceptions of Sexual Love in Elizabethan Comedy
}

Elizabethan romantic comedy is traditionally regarded as a dramatic form that can be distinguished as a generic celebration of marriage. Contrasting the erotic teleology of romantic comedy (which she calls "pure comedy") with the moral corrective of satire and the tragicomic emphasis on plot, Helen Gardner has written that "the great symbol of pure comedy is marriage, by which the world is renewed, and its endings are always instinct with a sense of fresh beginnings. Its rhythm is the rhythm of the life of mankind, which goes on and renews itself as the life of nature does. ... The young wed, so that they may become in turn the older generation, whose children will wed, and so on, as long as the world lasts. . . . The end of comedy declares that life goes on." 1

In romantic comedy, then, the sexual love that leads to marriage symbolizes the ongoing life of society, which in Elizabethan terms suggests a spiritually integrated cosmos. Although recent scholarship has been carefully dissecting the ideological program that sustains this comic syndrome, pointing to the devious subversions of its unity and the complex qualifications of its ideals, no analysis has disputed that the multileveled idealization of marriage is a powerful informing presence in Elizabethan comedy. ${ }^{2}$ Yet this celebra-

I. Helen Gardner, "As You Like It," in Modern Shakespearean Criticism: Essays on Style, Dramaturgy, and the Major Plays, ed. Alvin B. Kernan (New York: Harcourt, Brace \& World, 1970), pp. I93-94.

2. See, e.g., Louis Adrian Montrose, “'Shaping Fantasies': Figurations of Gender and Power in Elizabethan Culture," Representations, I (Spring I983), 


\section{Conceptions of Sexual Love in Elizabethan Comedy}

tory sexual and social configuration, which Shakespeare discerned and exploited until it had been thoroughly imagined and expressed, was by no means always developed or even implicit in earlier Elizabethan comedies. John Lyly was the first Elizabethan playwright to clarify the aesthetic realization that the theme of erotic love could be used to organize the disparate materials of early romantic comedy into a coherent design; but unlike the comedies of Shakespeare, Lyly's plays never acclaim sexual love and rarely end in a festive celebration of marriage. This chapter seeks to trace the ways in which Elizabethan comic form developed in plays by Lyly, Robert Greene, and Shakespeare in accordance with the precise erotic teleology Gardner describes by relating changes in the dramatic representation of love and marriage to similar patterns of change in conceptualizations of love and marriage in the nondramatic literature, particularly in Elizabethan moral and religious writing, including sermons and courtesy and conduct books.

Two salient modes of conceptualizing eros and marriage emerge from the complex controversy over changing sexual values articulated in Elizabethan conduct literature: a dualistic sensibility, in which sexual love is idealized beyond physical existence on the one hand or derided as lust on the other, and which views marriage as a necessary evil; and a more realistic, multifaceted sensibility, which, while retaining much of the skepticism about erotic love contained in the first view, nevertheless begins to conceive of affectionate marriage with great respect as the basis of an ordered society. Taking into account the inevitable overlapping and intermingling of shifting values and attitudes, historians have shown that in late sixteenth- and early seventeenth-century England, the second sensibility was gaining ground over the first. ${ }^{3}$ What I suggest is a parallel development between this shift in mentalité and the changing representations of sexual love and marriage that characterize the growth of Elizabethan comedy: Lyly, whose comic structures

6I-94; and Phyllis Rackin, "Androgyny, Mimesis, and the Marriage of the Boy Heroine on the English Renaissance Stage," PMLA, IO2 (January 1987), 29-4I.

3. This change in sensibility is particularly apparent in the upper and middle classes, to whom my remarks are limited. The most comprehensive treatment of this subject is Lawrence Stone, The Family, Sex and Marriage in England, 1500-1800 (New York: Harper \& Row, 1977). 


\section{The Expense of Spirit}

embody the dualistic sensibility, was unable to develop romantic comedy beyond a certain point; Greene developed the form to a limited extent; and Shakespeare brought it to fruition with As You Like It and Twelfth Night, dramatizing more complex representations, in which sexual love and marriage have acquired greater centrality and prestige.

My purpose in comparing the changing attitudes articulated in Renaissance sexual discourse to the altering dramatic representations of sexual love is not, therefore, to demonstrate causal connections between them, but to show that the concepts and values that inform the one can be seen as informing the other, and that the shifts discernible in one form are similarly discernible in the other. As a result my method involves suggesting reciprocal influences among kinds of evidence often thought to have a different value: the imagination of the individual artist, the aesthetic requirements of the comic form, and contemporary moral and religious writings about love and marriage. What emerges is a picture of alterations in the sexual conditions of possibility in the English Renaissance that suggests a new perspective on the cultural context and development of Elizabethan comedy.

ii

Lawrence Stone and other historians of the relations between the sexes have demonstrated convincingly that the institution of marriage enjoyed a considerable rise in prestige in post-Reformation England. ${ }^{4}$ The precise origins and chronology of this change in sensibility are as difficult to determine as is the actual sexual conduct of medieval and Renaissance men and women. In terms not of actual behavior, but of the moral prestige granted to heterosexual love and marriage, however, it is clear that those medieval conceptualizations of heterosexual relations which were officially articu-

4. See, e.g., Stone, pp. I35-38. Also see Christopher Hill, "The Spiritualization of the Household," in his Society and Puritanism in Pre-Revolutionary England (New York: Schocken Books, I964), pp. 443-8I; and C. L. Powell, English Domestic Relations, 1487-1653 (New York: Columbia University Press, 1917). 


\section{Conceptions of Sexual Love in Elizabethan Comedy}

lated by homilists, theologians, and poets of ten stressed and valorized asceticism.

Once made, such a generalization about centuries of thought, feeling, and representation must of course be qualified. Caroline Walker Bynum has definitively demonstrated that the modern scholarly emphasis on medieval asceticism is based on a radical privileging of genital sexuality and an accompanying disregard of the wide range and detailed exploration of erotic feeling and representation that characterize medieval spirituality. It is also true that a commonsensical, concrete counterideal of married love existed among ordinary people throughout the Middle Ages. ${ }^{5}$ Yet for purposes of this discussion, which centers on the rising prestige of the secular institution of marriage in sixteenth- and seventeenthcentury England, it remains appropriate to stress the striking contrast with the late medieval idealization of celibacy. Sexual love was considered out of the question as a basis for marriage, which the upper classes regarded as an alliance for the enhancement of family property and as an outlet for the avoidance of fornication. It is true that Saint Jerome, who felt that love between men and women was at best "to be endured, not enjoyed," and preferably "to be avoided if at all possible," represents the extreme of medieval opinion; nevertheless, carnal love, even for purposes of procreation, was usually conceptualized as tainted with some odor of sin and was at best regarded as morally neutral. Celibacy was upheld as the ideal behavior to be emulated, not only by priests and nuns, but by the whole community. ${ }^{6}$ Even Saint Paul, cited so often by sixteenth- and seventeenth-century Protestant preachers

5. Caroline Walker Bynum, Jesus as Mother: Studies in the Spirituality of the High Middle Ages (Berkeley: University of California Press, 1982), esp. pp. I I0-69, and "The Body of Christ in the Later Middle Ages: A Reply to Leo Steinberg," Renaissance Quarterly, 3 (Autumn I986), 399-439. See also Henry Ansgar Kelly, Love and Marriage in the Age of Chaucer (Ithaca, N.Y.: Cornell University Press, 1975), pp. 247, 284-85, 300, 31 5; Jane Tibbetts Schulenburg, "The Heroics of Virginity: Brides of Christ and Sacrificial Mutilation," in Women in the Middle Ages and the Renaissance: Literary and Historical Perspectives, ed. Mary Beth Rose (Syracuse, N. Y.: Syracuse University Press, I986), pp. 29-72; and Western Sexuality: Practice and Precept in Past and Present Times, ed. Philippe Ariès and André Béjin, trans. Anthony Forster (Oxford: Basil Blackwell, I985).

6. Kelly, p. 3 is; Stone, p. I35. 


\section{The Expense of Spirit}

as the main scriptural authority in their vehement defenses of marriage, could be seen to consider marriage as merely a necessary evil: "For I would that all men were even as I myself am . . . [i.e., celibate]," he writes in I Corinthians. "It is good for them if they abide even as I doe. But if they cannot absteine, let them marrie: for it is better to marrie then to burne" (7.7-9).

During the English Renaissance, conjugal loyalty and affection replaced celibacy as the officially idealized pattern of heterosexual conduct. ${ }^{7}$ Like other forms of medieval thought, however, much of the consciousness of love, marriage, and sexuality persisted into the Renaissance. ${ }^{8}$ Stone reports that "marriage among the property-owning classes in sixteenth-century England was . . . a collective decision of family and kin, not an individual one. . . Property and power were the predominant issues which governed negotiations for marriage." Individual, rather than parental choice of a spouse, let alone prior affection between potential mates, seemed foolish, undesirable. The eminent sixteenth-century humanist Vives, whose works were accessible in English, observes, for example, that "they that mary for loue shall leade theyr lyfe in sorowe." 10 Montaigne, whose translated essays were also available after I 603, is less hostile to erotic love than Vives; nevertheless, he affirms what he construes to be the essential incompatibility of erotic love and marriage:

Loue disdaineth a man should holde of other then himselfe, and dealeth but faintly with acquaintances begun and entertained under another title; as marriage is. Alliances, respects and meanes, by all

7. Stone, pp. I35-38; Hill, pp. 443-8I. Also see Louis B. Wright, MiddleClass Culture in Elizabethan England (Chapel Hill: University of North Carolina Press, 1935), pp. 20I-27; Ian Maclean, The Renaissance Notion of Woman (Cambridge: Cambridge University Press, 1980), p. 59; and Carroll Camden, The Elizabethan Woman (New York: Elsevier, I952), pp. I09-49.

8. Linda T. Fitz, "What Says the Married Woman: Marriage Theory and Feminism in the English Renaissance," Mosaic, I 3 (Winter I980), I-22; Peter Laslett, The World We Have Lost: England before the Industrial Age (New York: Scribner's, I965), pp. I30-3 I.

9. Stone, p. 87.

10. John Louis Vives, Instruction of a christen woman, trans. Rycharde Hyrde ( I 529 ; rpt. London, I 557), bk. I, chap. I6, "Howe the mayde shall seeke an husbande." 


\section{Conceptions of Sexual Love in Elizabethan Comedy}

reason, waighe as much or more, as the graces and beawtie. A man doth not marrie for himselfe, whatsoever he alledgeth; but as much or more for his posteritie and familie. The use and interest of mariage concerneth our off-spring, a great way beyond us. Therefore doth this fashion please me, to guide it rather by a third hand, and by anothers sence, then our owne: All which, how much doth it dissent from amorous conventions? . . . I see no mariages faile sooner, or more troubled, then such as are concluded for beauties sake, and hudled up for amorous desires. There are required more solide foundations, and more constant grounds ... this earnest youthly heate serveth to no purpose. ${ }^{11}$

Furthermore, while celibacy no longer flourished as an idealized mode of behavior after the Reformation, the distrust of sexual desire and the ideals of maidenly virtue-virginity-and wifely chastity continued to preoccupy the Renaissance imagination of the moral and spiritual life well into the seventeenth century.

It is worth dwelling briefly on the tremendous spiritual weight put on sexuality in the Renaissance. A good example is the emphasis placed on premarital female virginity. Many have argued that the perceived necessity for premarital female chastity, as well as the double standard of sexual morality, arose originally from the economic need to legitimize property for the purposes of inheritance; ${ }^{12}$ however this may be, the ideal of virginity accrued moral and theological overtones and became for poets a useful means of dramatizing female social and spiritual life. One need only think of Britomart, Spenser's embattled knight of chastity, dueling her way through a world full of erotic peril. In the courtesy book Instruction of a christen woman ( I 529), dedicated to Catherine of Aragon, Vives elaborates powerfully the consequences that loss of virginity entails for a young woman:

Turn hir whiche way she will, she shall fynde all thynges sorowfull and heauy, walyng and mourning, and angry and displeaserfull. What sorowe will hir kynneffolkes make, when euery one shall thynke them selfe dysshonested by one shame of that maide?

I I. Michaell de Montaigne, The Essayes, trans. John Florio (London, I603), p. 5 IO, italics his.

I2. Stone, p. 637; Keith Thomas, "The Double Standard," Journal of the History of Ideas, 20 (1959), I95-2 I 6. 


\section{The Expense of Spirit}

What mourninge, what teares, what wepyng of the father and mother and bryngers up? Doest thou quiete theim with this pleasure for soo muche care and labour? Is this the rewarde of the bringyng up? What cursyng will there bee of hir acquaintance? . . . What mockinge and bablynge of those maides, that enuied hir before? What a loathynge and abhorrynge of those that loued hir. What flyinge of hir company . . . when euery mother wyll keepe not onely their daughters but also their sonnes from the infection of such an unthryftie mayde. And wooars also, if she had any, all flee away from hir. . . I reherce the hate and angre of folkes for I knowe that many fathers have cut the throtes of their daughters, bretherne of their sisters, and kinnesmen of their kynneswomen. ${ }^{13}$

Could any young woman possibly have endured such an onslaught of threatened damnation, social ostracism, personal guilt and despair, open ridicule, and family catastrophe? In a chapter discussing when a maid should leave the house (to which his answer is never, unless absolutely necessary, and in that case certainly never alone), Vives evokes a world of sexual desire that, like the world of Spenser's Britomart, is fraught with spiritual dangers. "Howe so euer she turneth hirselfe from god unto men, whether shee like them or be liked of them, shee forsaketh Christe, and of Christes spouse sodeynly becometh an adulterer." ${ }^{14}$ This statement, striking in its lucidity, starkly conveys the perils of sexuality, the evils of it, and the human responsibility for it; Vives has here clarified the association of sexuality with sin. Female entrance into the sexual world, whether through body or mind, by choice or unwittingly, whether by reciprocating male affections or merely remaining the passive object of them, is equivalent to sin, is sin. Even when sexual love is viewed with a less foreboding gloom, it is of ten regarded as bitterly degrading, bestial, and absurd. Once again we can turn to Montaigne for the liveliest and most direct articulation of this attitude:

When all is done, I finde that loue is nothing els but an insatiate thirst

I3. Vives, bk. I, chap. 7, "Of the kepying of virginitee and chastitee."

I 4. Vives, bk. I, chap. I2, "How the mayde shall behaue hyr selfe forth abrode." 


\section{Conceptions of Sexual Love in Elizabethan Comedy}

of enioying a greedily desired subiect . . . which becometh faulty by immoderation $\&$ defectiue by indiscretion. . . . Now considering oftentimes the ridiculous tickling, or titilation of this pleasure, the absurd, giddie and harebraind motions wherewith it . . . agitates . . . that unaduised rage, that furious and with cruelty enflamed visage in loues lustfull and sweetest effects: and then a grave, sterne, severe surly countenance in so fond-fond an action . . . I beleeue that which Plato sayes to be true, that man was made by the Gods for them to toy and play withall. . . . And that nature in mockery leaft us the most troublesome of our actions the most common: thereby to equal us, \& without distinction to set the foolish and the wise, us and the beasts. ... In all other things you may observe decorum, and maintaine some decencie: . . . this cannot onely be imagined, but vicious or ridiculous. ${ }^{15}$

Moral bankruptcy and degeneracy, fear, humiliation, and a kind of ridiculous madness: what fools these mortals be! Such negative associations are made over and over again in Renaissance discussions of the place of sexuality in social and moral life. But were there not more positive conceptions of erotic love-beyond, that is, such occasional, begrudging tributes as Robert Burton's parenthetical concession that love "by a perpetual generation makes and preserves mankind, propagates the Church"?16 One answer, of course, is that just as classical writers had treated love both philosophically and sensually, so Christian writers recognized both a sacred and a profane love. ${ }^{17}$ This dualistic, idealizing cast of thought granted love the highest respect and prestige when it was conceived of either as separate from, or as having transcended, sexual desire. I cannot do justice here to the profound and complex legacy that the Renaissance inherited from this mode of conceptualizing love, which had been articulated systematically in Christian orthodoxy. ${ }^{18}$ But of the many literary variations on the theme

I5. Montaigne, p. 527, italics his.

I6. Robert Burton, The Anatomy of Melancholy, in Seventeenth Century Prose and Poetry, ed. Alexander M. Witherspoon and Frank J. Warnke (New York: Harcourt, Brace \& World, I963), p. I92.

I7. John Charles Nelson, The Renaissance Theory of Love (New York: Columbia University Press, I958), p. 67.

I 8. See, for example, Irving Singer, The Nature of Love (Chicago: University of Chicago Press, I984); Maurice Valency, In Praise of Love (New York: 


\section{The Expense of Spirit}

of this tradition that are of immediate relevance to English Renaissance drama, Neoplatonism and the related phenomenon of Petrarchism are salient.

The ideas of the Florentine Neoplatonist Marsilio Ficino are expanded and popularized in Castiglione's The Courtier, which was translated by Thomas Hoby in I56I. In the fourth book of The Courtier the favored figure of the ladder of love, inherited from Plato's Symposium, is set forth in eloquent detail. In this image the beauty of the female beloved inspires the male lover to ascend by stages a metaphorical ladder, leading him to the beauty that "shall make a universal conceite, and bring the multitude of them to the unitie of one alone, that is generally spred over all the nature of man." Now able to ascend by contemplating its own beauty, the soul of the lover then transcends this stage, along with all earthly things, to gaze on "the maine sea of the pure heauenly beautie." Castiglione allows for the appropriateness of sensual love in the young, but the mature, civilized society has transcended sexuality. Whereas the female beloved serves the crucial but limited function of original inspiration, the true Neoplatonic lover will keep "alwaies fast in minde, that the bodie is a most diverse thing from beautie, and not onely not encreaseth, but diminisheth the perfection of it." The speech in which the ladder of love is described includes many of the characteristically idealistic love themes: sacrifice (in this case of the soul to God through burning or consuming of the body), liberation from the self, transcendence, transformation, the ideals of contemplation and union with God. ${ }^{19}$

Sears Jayne points out that Platonism became permanently associated in the English Renaissance with Petrarchism. ${ }^{20}$ The Neoplatonic ideas of love both as "a cosmic phenomenon informing the universe and apparent in nature" and as an independent force transcending nature and creating its own world directly influenced

Octagon, I975); and Denis de Rougemont, Love in the Western World, trans. Montgomery Belgion (New York: Harcourt Brace, I940).

19. Baldesar Castiglione, The Courtier, trans. Thomas Hobby (London, I 588). See bk. 4, which Hobby describes as telling "of honest loue."

20. Cited in Neal L. Goldstein, "Love's Labor's Lost and the Renaissance Vision of Love," Shakespeare Quarterly, 25 (Summer I974), 339. 


\section{Conceptions of Sexual Love in Elizabethan Comedy}

the Petrarchan tradition through Castiglione and Pietro Bembo. ${ }^{21}$ As in Castiglione, the beloved in Petrarch's poetry remains an idealized, unattainable icon. Although in Petrarch the lover oscillates "between restrained wooing and distant adoration," actual union is envisaged only in dreams. Leonard Forster stresses the central importance of the lover's experience of love as dual, as "interpenetration of pleasure and pain. . . The elaboration and exploitation of antitheses is the essence of Petrarchism."22 The Petrarchan style and diction, which reached England via Wyatt and Surrey in the first half of the sixteenth century, was most notably exploited in the latter half by Sidney, Spenser, and Shakespeare and their followers in the numerous, fashionable sonnet sequences of that period, sequences that created an image of a courtly, melancholy, obsessive lover, doomed to frustration and rejection, a little foolish for putting so much hope and faith in the desire for a woman.

According to the mentality being described, sexual desire, even when conceived as leading to a consciousness of the divine, was never considered beneficial or good in itself. Loved women were better left exalted, remote, and untouched. It is therefore not surprising to discover that where idealization of women occurred, misogyny was rarely far behind. With significant exceptions, English Petrarchism and its corollary, anti-Petrarchism, tend to articulate that consciousness which exalts and idealizes the image of Woman while simultaneously regarding actual women with neglect or contempt. ${ }^{23}$ Notwithstanding the persistence of this mode of thought in our culture, what is both new and significant in the English Renaissance is that this dualizing, polarizing consciousness begins to break down, to lose its authority as the predominant, or at least as the only, articulated view of women and sexuality. A burgeoning awareness of a more complex, problematic moral and emotional reality ensues; and it is in this changing moral atmo-

2 I. Leonard Forster, The Icy Fire: Five Studies in European Petrarchism (Cambridge: Cambridge University Press, I969), p. 2 I.

22. Forster, pp. I-6o.

23. Regarding exceptions, see, e.g., C. S. Lewis's discussion of Spenser as the poet of married love in The Allegory of Love: A Study in Medieval Tradition (London: Oxford University Press, 1977), pp. 297-360. 


\section{The Expense of Spirit}

sphere that romantic comedy, with its celebration of married love, comes into its own as a dramatic form.

In the development under discussion, the work of John Lyly represents an encounter between the dualistic, idealizing Petrarchan sensibility to which he was heir and the more realistic, multifaceted view of married love that was beginning to announce its presence both in the drama and in the moral and religious outpourings of the surrounding society. ${ }^{24}$ Lyly was the first major Elizabethan playwright to recognize the importance of the erotic love theme to the coherence and design of his plays; consequently, he was the first to organize romantic comedy by subordinating the disruptive medley of spectacle, song, ritual, pageant, magic, folklore, slapstick, and farce that constituted it to a central love story. Lyly emerged from the tradition of aristocratic early sixteenth-century humanism in which literature existed in service to the prince and the state, not as an independent profession. As G. K. Hunter has demonstrated, Lyly's values and beliefs, his apparent disdain of writing for the increasingly powerful, popular, public theater, doomed him to outlive his early success and to die in disappointed poverty, having hopelessly depended on favors from Queen Elizabeth that never were forthcoming. ${ }^{25}$ But the anachronistic humanist idealism that tied Lyly to an outmoded literary tradition caused him to conceive of his plays as select entertainments, dramatizations of the elegant, refined manners of a stately court; as a result, though Lyly retained many of the native traditions that gave Elizabethan comedies their vitality, he also imposed on them a new sense of integration, balance, and grace. Neverthe-

24. Cf. Robert Weimann, Shakespeare and the Popular Tradition in the Theater, ed. Robert Schwartz (Baltimore, Md.: Johns Hopkins University Press, 1978), p. 197: "It is a new sense of the interdependence of character and society, and a fully responsive interplay between dramatic speech and dramatic action in the process of reproducing the cause and eff ect of human behavior that defines 'realism' in the Renaissance theater." Weimann also makes the point (p. I73) that Lyly stood "at the very threshold" of such a complex apprehension, remaining "too bewildered to realize that the contradictions (which he points out) are about to yield a new and superior kind of unity."

25. G. K. Hunter, John Lyly: The Humanist as Courtier (London: Routledge \& Kegan Paul, 1962). 


\section{Conceptions of Sexual Love in Elizabethan Comedy}

less, the lack of flexibility in his conception of sexual love prevented Lyly from developing romantic comedy in accordance with the changing sensibility around him.

In his early success, Euphues (I 578), and its successor, Euphues and His England (1580), Lyly creates an image of love and sexuality that he develops throughout his plays, and that is recognizable as emanating from that polarizing consciousness which posits idealization of women or misogyny, chaste worship or lust, as the only possibilities for love. In these two tracts, Lyly establishes a prose style that, with its witty similitudes, puns, antitheses, and parallelisms, mirrors his ideal of a learned, courtly, graceful, and sophisticated society. As a means of recommending manners and morals to their readers, both of these courtesy books relate the adventures of two elegant young men, Euphues and Philautus, whose coming of age Lyly depicts as an ongoing encounter with temptation in the form of love and desire. In the indiscriminate, capricious fickleness of most of the female characters and the continually wrongheaded, hopelessly infatuated state of Philautus, Lyly depicts sexual desire as a compulsive, impersonal, and ridiculous passion, which can be understood only as a direct contrast to reason and wisdom. "What new skirmishes dost thou now feele betweene reason and appetite, loue and wisdom, daunger and desire" Philautus asks, rhetorically echoing conventional Petrarchan sentiments and antitheses. All in all we are expected to perceive that "the desease of loue . . . is impatient, the desire extreame, whose assaultes neyther the wise can resist by pollicie nor the valiaunt by strength." One wants to protest that the sensible could ignore this self-indulgence by intelligence, so utterly self-centered, obsessive, and infantile an experience does love become when Lyly presents it. As might be expected, Euphues' heroism consists in his transcending sexual desire, his realization that "the effect of loue is faith, not lust, delightfull conference, not detestable concupiscence, which beginneth with folly and endeth with repentaunce."26 At the end of Euphues and His England we find this polarized perspective figured forth concretely. In a concluding diatribe, Euphues, having returned to Italy from a visit to England determined to devote the

26. John Lyly, Euphues and His England, in The Complete Works of John Lyly, vol. 2, ed. R. Warwick Bond (Oxford: Clarendon, I902), pp. 89-II2, I58. 


\section{The Expense of Spirit}

remainder of his life to solitary idealization of the Virgin Queen, exhorts the Italian women, whom he misogynistically maligns, to be like the English women, whom he sentimentally idealizes. Philautus ends up in a second-best, rebound marriage that pointedly does not ensue from any of his perpetual courtships.

This configuration, in which love remains a marginal experience, finding fulfillment either in the dream life or in an unsatisfactory lowering of expectations, becomes a structural principle in Lyly's plays. Sapho and Phao (I 584) concludes with the image of an idolized female monarch, victorious over desire and remaining an object of the chaste, constant adoration of a solitary admirer and subject. Although Endymion (I 588) ends with several happy couplings, the hero of the play conceives an impossible, idealizing love for the Moon, who, descending to the action in the form of a chaste and benevolent queen, rewards the hero for his solitary devotion by restoring his youth and granting him permission to worship her from afar for the rest of his life with celibate, contemplative, Neoplatonic joy.

Lyly's preference, clearly, is for sublimation; and his habitual tendency is to dissociate sexual love, which he distrusts, from social order, which he idealizes. In Lyly's earliest play, Campaspe (I584), a distracted Alexander the Great at last magnanimously transcends his love for a lower-class woman who does not return it. The potential threat to the orderly, efficient running of society implicit in Alexander's sexual desire is domesticated to a harmless, frivolous interlude, a digression in the career of his greatness. Lyly replicates this situation in Sapho and Phao: the virtuous monarch, Sapho, overcomes her unseemly attraction to a lower-class boatman, Phao, and usurps the capricious authority of Venus by capturing Cupid, in an elegant victory over desire.

In Lyly, then, sexual desire, though powerful and unavoidable, cannot be incorporated in a civil, humane society. Instead it must be conquered, overcome. Lyly accounts mythically for the inevitable association of chaos and sexuality in one of his most absurd, charming, and misogynistic plays, The Woman in the Moon (1 593). Here his conception of female weakness and duplicity is allegorized in Pandora, a drastic parody of the remote, idealized Petrarchan lady. Pandora, a sort of ur-woman, is created by Nature and then abandoned to the whimsical mercy of the envious planets. In a 


\section{Conceptions of Sexual Love in Elizabethan Comedy}

mad, obsessive, and uncivil chase, several shepherds pursue the helplessly victimized, indiscriminate, perpetually inconstant and deceptive Pandora through a series of comically futile attempts to possess her. In one of Lyly's repeated images of sexual desire, Pandora, like the heroine of Euphues, ends by being attracted to a clown.

In spite of Pandora's outrageous behavior, the real cause of these ridiculous effects is actually male desire. The play begins with an image of the longing shepherds kneeling to Nature, begging and praying for the creation of a female. The three reasons the shepherds give for desiring a woman turn out to be the very reasons cited in the Elizabethan Book of Common Prayer as the justifications for marriage: the procreation of children, the avoidance of fornication; and the need for companionship. ${ }^{27}$ Nevertheless, marriage, if and when it enters the scene at all, has little prestige in a Lyly play. The shepherds in The Woman in the Moon end by praising a single life, while Pandora is assigned to permanent residence in the moon-remote and heavenly, but also wayward, fickle, and false.

It should be emphasized that although erotic love, which, with one exception, is always Lyly's subject, is continually presented in his work as a threat to the brilliant, graceful society patterned in Euphuistic prose, the tone of his comedies is invariably delicate, witty, and light. This refinement of mood is partially achieved by the ordered introduction of the mixture of musical, magical, folkloric, allegorical, and mythological material which Elizabethan comic playwrights loved: singing and dancing; magic fountains and wells; Ovidian transformations; gods and goddesses; fairies and monsters; ugly, wise old hags who speak with the cynical clairvoyance of desire. All of these characters and motifs, woven together with witty repartee, constitute not a narrative of rising intensity with which we are asked to identify, but a series of static tableaux, balanced against one another, that we are asked to admire. ${ }^{28}$

Lyly's allegorical characters and static, balanced scenes serve as emotional distancing devices. M. C. Bradbrook has noted aptly

27. The First and Second Prayer Books of Edward VI (I 549; rpt. London: J. H. Dent, I949), pp. 252-58.

28. Cf. Hunter, p. I03. 


\section{The Expense of Spirit}

that in Lyly's comedies passion is merely a postulate; ${ }^{29}$ the evocation of felt emotion is not part of the playwright's courtly representation of love as a wooing game, a witty lark that provides an amusing, if occasionally dangerous, diversion from the serious activities of society. When erotic love is first appropriated from the Petrarchan lyric and begins to be dramatized, it is seen as abstract, magical, playful.

Along with the fact that erotic love is dramatized abstractly as a frivolous game, I believe there is another reason why Lyly's basically negative and skeptical portrayal of love and sexuality never violates the brittle whimsy of his comedies. Although sexual desire, whether or not it leads to marriage, is viewed by Lyly and many others as dangerous, humiliating, anarchic, and absurd, still the consequences of indulging it appear determined beforehand. There is no need to take a complicated, certainly not a suspenseful, view of the matter; the moral position of sexuality is fixed and predictable: "All this the world knows . . . well." What I am suggesting is that the consciousness that polarizes love is inherently undramatic. ${ }^{30}$ This dichotomizing perspective, in which love becomes either degrading lust or spiritual idealization, traditionally took poetic form in the lyric, a genre designed to explore individual emotion, not to represent situational conflicts that drive toward resolution among various characters. Lyly's sense of dramatic conflict is epitomized in Campaspe, in which, in a story of unrequited love, he never once dramatizes a scene alone between the frustrated, powerful lover Alexander the Great and his unresponsive, captive beloved, Campaspe. As a result, love is depicted as an isolating, self-absorbed experience; the meaningful conflict is clarified not as an emotional struggle between Alexander and Campaspe, but as an abstract debate taking place in Alexander's

29. M. C. Bradbrook, The Growth and Structure of Elizabethan Comedy (Cambridge: Cambridge University Press, I979), p. 65.

30. Cf. Robert J. Meyer, “'Pleasure Reconciled to Virtue': The Mystery of Love in Lyly's Gallathea," Studies in English Literature, 2 I (I98I), 193-208, in which the author correctly warns us not to assess Lyly's "masque-like" and "non-developing" drama in terms other than its own. My purpose is not to judge Lyly's dramaturgy as inferior, but to point out why, given his moral perspective on sexual love and his structural techniques, Lyly could develop romantic comedy only to a limited extent. 


\section{Conceptions of Sexual Love in Elizabethan Comedy}

mind, an intellectual exercise. Furthermore, in an imaginative vision that, like Lyly's, idealizes the superiority of the elegant, contemplative soul, which has managed to remove itself from the muddy contingencies of physical existence, we must recognize a level of perception that is profoundly anticomic, particularly insofar as comedy is associated morally, emotionally, psychologically, and symbolically with birth, rebirth, the cycle of the seasons, with ongoing, natural life. ${ }^{31}$

Northrop Frye has clarified the necessary structural relationship between fulfilled sexual love and the form of romantic comedy as Shakespeare discerned and perfected it. Frye shows that the sense of vitality underlying comedy often takes the form of a drive toward identity that, in romantic comedy, is always erotic. The harsh and irrational laws impeding the fulfillment of the sexual drive of the hero and heroine must be overcome in order to bring about the freedom and self-knowledge that will form the basis of the new society symbolized in the festive conclusion. Romantic comedy, then, dramatizes that longing for a happy ending which is a wish-fulfillment fantasy of attaining all of one's desires without social, emotional, or moral cost: "Jack shall have Jill / Nought shall go ill." It should be mentioned that by wish-fulfillment Frye does not mean escapism, although romantic comedy can serve that purpose. Frye stresses instead what he calls "an imaginative model of desire." In his comedies Shakespeare pits the world of individual imagination and sexual desire against the more tangible world of social and historical fact, causing the spectator to question the reality of both worlds and then reconciling the claims of both in a final, inclusive vision of the social and spiritual harmony symbolized in marriage. ${ }^{32}$

31. See Susanne K. Langer, Feeling and Form (London: Routledge \& Kegan Paul, I953), pp. 326-50.

32. Northrop Frye, A Natural Perspective (New York: Columbia University Press, I965), p. I I7. See also his "The Argument of Comedy," in Kernan, pp. I65-73, and Anatomy of Criticism (Princeton, N.J.: Princeton University Press, I957), p. I 84. Cf. Montrose, who points out (p. 69) that "Frye's account of Shakespearean comic action emphasizes intergenerational tension at the expense of those other forms of social and familial tension from which it is only artificially separable; in particular, he radically undervalues the centrality of sexual politics to these plays by unquestioningly identifying the 


\section{The Expense of Spirit}

Interestingly, in a later play, Mother Bombie (1589), Lyly moves toward a comic plot in which wit and vitality are joined to sexual desire. But the emphasis in this play remains with the servants' intriguing, not with the inherent drama of erotic love that gives shape to romantic comedy. Love still is not represented as a felt emotion. Lyly consequently fails to unite love with marriage. G. $\mathrm{K}$. Hunter believes, not without justice, that what Lyly gains in narrative and integrative power in this play, he sacrifices in delicacy and grace. ${ }^{33}$

The fact that Lyly moves in Mother Bombie toward an uncharacteristically festive conclusion celebrating marriage, no matter how unsuccessful the attempt, indicates that he is beginning to detect a more profound pattern at the heart of the comic form. Although Lyly can discern this possibility, his polarized conception of love and sexuality prevents him from either fully imagining its ramifications or realizing them artistically. These achievements instead can be found to coexist in the drama with a different set of articulated beliefs which, while retaining much of the Renaissance sense of the wicked bestiality and folly of sexual desire, nevertheless includes these skeptical elements in a larger configuration that unites love with marriage and conceives of the combination as the foundation of an ordered society. I am not, of course, arguing that polarized conceptions of love and sexuality, expressed in Neoplatonic and Petrarchan patterns and images, disappeared from post-Lylyan Elizabethan comedy, but that these conceptions became part of an expanded vision that incorporates the dualistic

heroines' interests with those of the heroes." Although Frye needs a corrective, it remains true that in Shakespearean romantic comedy, much of the point is that the heroine herself comes to identify her interests with those of the hero; this syndrome, in fact, may be seen as the location of the comic wish-fulfillment generated by the male perspective, including both Frye's and Shakespeare's. The conservatism of Shakespearean comedy in terms of sexual politics can best be perceived in contrast to the satiric comedies and tragedies written by his contemporaries, where the inequities of the Jacobean sexual hierarchy are not suppressed, but themselves constitute the subject of various plays. See Chapters 2 and 3 of this book. The best critique of Frye appears in Fredric Jameson, The Political Unconscious: Narrative as a Socially Symbolic Act (Ithaca, N. Y.: Cornell University Press, I98I), esp. pp. 68-74.

33. Hunter, pp. 227-28, 243. 


\section{Conceptions of Sexual Love in Elizabethan Comedy}

sensibility but is not limited to it. The fact that romantic comedy, a dramatic form celebrating erotic love and marriage, flourished in the environment of a new sensibility which embraced marriage both as the spiritual foundation of society and as the repository of hope for personal happiness strongly suggests a parallel development between the increasingly complex, optimistic comic representations of eros that followed Lyly's plays and the more positive, complex, moral conceptions of sexual love and marriage that were beginning to be articulated in Protestant conduct literature.

iii

Although it did not originate with the Protestant (largely Puritan) theologians of the sixteenth and early seventeenth centuries, this optimistic vision of marriage was articulated explicitly, fully, and repeatedly by them. As Lawrence Stone points out, "Sanctification of marriage- 'holy matrimony' - was a constant theme of Protestant sermons . . . which were directed to all classes in British society." 34 More than forty-five years ago, in a seminal article entitled "The Puritan Art of Love," William and Malleville Haller showed that "it was the Puritan preachers who set forth an ideal pattern of love and marriage based upon traditional Christian morality, vitalized for popular imagination in terms of the English Bible, and adapted to the new conditions in which men were having to live." 35

Reiterating the holiness of the married state, the Puritan preachers went about idealizing marriage and the family with all the fervid determination that their Catholic forefathers had lavished upon celibacy and virginity. The Puritans no longer felt the need to attack the prestige of celibacy: "There is no man now so dull as to think it is a sin to marry," Heinrich Bullinger announces confidently in the important Golden boke of christen matrimonye, translated by Miles Coverdale in I $543 .{ }^{36}$ In the Puritan outpourings of

34. Stone, pp. I35-36.

35. William Haller and Malleville Haller, "The Puritan Art of Love," Huntington Library Quarterly, 5 (1941-42), 242.

36. Heinrich Bullinger, The golden boke of christen matrimonye, trans. Miles Coverdale, with a preface by Thomas Becon (London, I 543). Cf. William 


\section{The Expense of Spirit}

sermons, conduct books, and spiritual autobiographies, marriage becomes "the type and source of all human relations, the seminary and model of all polities, the church and the state in little, the image and reflection of Christ's union with his elect." 37 John Dod and Robert Cleaver's influential courtesy book, $A$ Godlie forme of householde Government (I 598), makes it plain that the proper running of one's household had become, like the preservation of virginity, a matter of the greatest spiritual importance, of salvation and damnation. ${ }^{38}$

Several salient themes mark those Puritan tracts which idealize marriage as the basis of an ordered society. First, rather than stressing the avoidance of fornication or even the procreation of children, these documents emphasize a third motive for marriage, which was added by Archbishop Thomas Cranmer to the Book of Common Prayer in I 549:39 companionship, or the relief of what Milton was later to call "that . . . God forbidden loneliness." ${ }^{40}$ This new emphasis on the spiritual, rather than the physical quality of the marriage relation, along with the Puritan stress on the unique relationship between each individual and God, accompanied a recognition of the value of individual, rather than parental, choice of a marriage partner, the importance of the woman as helpmate and companion, the need for love in marriage, and finally, the desire for personal happiness. ${ }^{41}$

Perkins, Christian Oeconomie or Houshold Government (London, I63I), in Workes, 3:683. Perkins sees celibacy as a kind of punishment for those isolated and marginal figures who are unable to participate in normal social life.

37. Haller and Haller, p. 270.

38. John Dod and Robert Cleaver, A Godlie forme of householde Government (London, I 598). See, e.g., "Epistle Dedicatorie."

39. See Stone, p. I36.

40. John Milton, The Doctrine and Discipline of Divorce, in John Milton: Complete Poems and Prose, ed. Merritt Y. Hughes (Indianapolis, Ind.: Odyssey, I957), p. 707.

4I. See Jack Goody, The Development of the Family and Marriage in Europe (Cambridge: Cambridge University Press, 1983), esp. pp. 24-26, where Goody argues that an emphasis on consent in marriage, or on the mutual affection of the conjugal couple, "was in no way peculiar to the English." Though Goody maintains that these emphases were inventions neither of English Protestantism nor of bourgeois capitalism, he does acknowledge "a general move away from the solidarity of kin groups to the independence of 


\section{Conceptions of Sexual Love in Elizabethan Comedy}

The Puritans linked happiness inseparably by hope to their ideal of love and marriage. In remarking drily that "it was a nice and subtle happiness these men conceived for themselves when they abandoned celibacy and embraced matrimony," the Hallers are referring to the latent contradictions in Puritan thought on this subject. ${ }^{42}$ While insisting on the obedience and subordination of women, for example, the Puritans simultaneously stressed woman's importance, both as a companion to her husband and as supervisor of the newly exalted household. ${ }^{43}$ Furthermore, the fact that Puritan doctrine gives woman's soul full equality with man's in the sight of God grants woman an undeniable dignity. Similarly, the Puritans continue to express a wholehearted distrust of sexual desire, dwelling-often with obsessive relish-on "abhominable adulterers, stinking whoremongers, uncleane fornicatours, and detestable Sodomites"; ${ }^{44}$ yet their perception that sex in the context of marriage - when practiced with moderation, of course, and as a solemn religious duty-is a "holy and undefiled action" 45 does grant consummated erotic love a distinct prestige. Further, although the Puritans strongly emphasize the importance of individual choice of a mate, deriding "the buying \& selling of children among parents ... [ [and] the forced marriages," 46 they nevertheless insist on parental consent to a match. Finally, though the preachers reiterate that adultery, which should be punished with death, is the only reason to dissolve a marriage, the logical extension of their arguments about the absolute necessity of companionship results eventually in Milton's divorce tracts, where, in arguments that surely would have horrified the preachers, Milton declares that incompatibility alone is sufficient cause to declare a marriage void.

the conjugal couple, and even of its constituent members as individuals." The main relevance of Protestant sexual discourse to this study, however, is not its originality, but the wide extent to which it repeated and disseminated these ideals and the problem of embodying them in social relations. See Introduction and Chapter 3 .

42. Haller and Haller, p. 250.

43. Hill, pp. 443-8I.

44. Becon, "Preface," in Bullinger.

45. Perkins, p. 689.

46. Samuell Hieron, "The Marriage Blessing," in The Sermons of Master Samuell Hieron (London, I635), p. 405. 


\section{The Expense of Spirit}

The Puritan tracts therefore constitute a complex expression of double-mindedness: women must be totally subordinate while also being fully capable and equal; freedom of choice in marriage must be pursued while absolute obedience to parents is maintained; individual personality and desire must be asserted and fulfilled, but spiritual authority and social stability must never be violated. The preachers did not acknowledge these potential contradictions, however much their unforeseen consequences may have revealed the strains inherent in them. It is one of the striking features of post-Lylyan romantic comedy that a similarly complex, apparently inconsistent or paradoxical awareness of the moral ambivalence of sexual desire, freedom of choice in marriage, and the social and spiritual position of women is both evoked and resolved; and that the reconciliation of these erotic tensions itself becomes the subject of the drama.

Robert Greene's popular comedy, Friar Bacon and Friar Bungay, written in $1589-90$ for the public theater, provides an excellent example of the reciprocal relation between this complex moral and sexual awareness and the development of romantic comedy. Friar Bacon is a characteristically chaotic medley, but as in a Lyly comedy, a dominant love story gives the play its shape. Unlike Lyly, however, Greene develops the love story as a conflict that arises from the diverse social, emotional, and sexual needs of three individuals and then moves through a suspenseful confrontation to a resolution in which all protagonists are married and happy. ${ }^{47} \mathrm{~A}$ brief review of the plot will recall how this works.

Edward, the Prince of Wales, amusing himself by hunting in the country, becomes infatuated with Margaret, a farmer's daughter, whom he attempts to seduce while disguised as a farmer. But Margaret is not interested, and, his ploy failing, Edward sends his friend Lord Lacy to plead his case for him. Lacy and Margaret fall in love. The germane point about this material is that Greene works through the ensuing erotic complications to a wish-fulfill-

47. See Norman Sanders, "The Comedy of Greene and Shakespeare," in Early Shakespeare, Stratford-upon-Avon Studies, no. 3, ed. J. R. Brown and B. Harris (London: Edward Arnold, I96I), p. 40. Sanders observes that Greene realized the dramatic possibilities of love- "the surprises, psychological quirks and inconsistencies of human love which constitute its logic in art as in life." 


\section{Conceptions of Sexual Love in Elizabethan Comedy}

ment conclusion in which "nought shall go ill" by dramatizing love and sexuality as variable, complex components in the moral and social lives of his characters. Edward, the future king of England, cannot possibly marry a commoner and is merely trifling with Margaret; unlike Lyly's Alexander, who overcomes his inappropriate infatuation in isolation and goes off alone to heroic martial exploits, Edward relents in a fully dramatized confrontation with Margaret and Lacy, from which he exits happily and honorably to marry the princess of his father's choice. Lacy, an earl, in turn proves his worthiness by ignoring conventional class barriers and marrying the farmer's daughter, Margaret of Fressingfield, the woman of his own personal choice. Interestingly, all of Edward's wooing is rhetorical, allegorical, and cast in the conventional antitheses of the Petrarchan lover. "Her bashful white mixed with the morning's red / Luna doth boast upon her love cheeks" (I. 56-57), he recites, recalling the Renaissance sense of the abstract impersonality of sexual desire. ${ }^{48}$ In contrast, Lacy speaks of his love with a straightforward passion full of concrete references to his immediate, individual situation: addressing Edward he says, "Love taught me that your honor did but jest / That princes were in fancy but as men, / How that the lovely maid of Fressingfield / Was fitter to be Lacy's wedded wife / Than concubine unto the Prince of Wales" (8. I9-23).

Finally, it is Margaret's character-her wit, vitality, gratitude, and chastity - that gives love its felicity and dignity, making possible the harmonious and stable society of the conclusion, in which the two marriages simultaneously take place. At one juncture, Margaret, wrongly thinking Lacy has betrayed her, decides to become a nun. "And now I hate myself for that I loved / And doted more on him than on my God . . . / All is but lust, but love of heavens" (I4.I3-I4, I 8), she says, despairingly polarizing the position of love in the moral life. But the point is that Margaret is in despair when she makes this speech. The scene in which Lacy confronts her in her nun's habit and persuades her to marry him

48. All quotations, identified in the text by scene and line numbers, are from Robert Greene, Friar Bacon and Friar Bungay, in Drama of the English Renaissance, vol. I: The Tudor Period, ed. Russell A. Fraser and Norman Rabkin (New York: Macmillan, 1976), pp. 359-82. 


\section{The Expense of Spirit}

reads like a final farewell to medieval ideals of love and sexuality: "Either a solemn nunnery or the court; / God or Lord Lacy. Which contents you best, / To be a nun, or else Lord Lacy's wife?" (I4.82-84). She replies, "The flesh is frail . . . / Off goes the habit of a maiden's heart; / And, seeing Fortune will . . . / All the shroud of holy nuns, farewell. / Lacy for me, if he will be my Lord" (I 4. 86, 89-92).

Thus does Friar Bacon provide a fledgling example of the way in which Elizabethan comedy, like the Puritan marriage tracts, manages to have things both ways. In the courtship of Lacy and Margaret, individual choice and sexual desire leading to marriage are conjoined and affirmed. But Greene also suggests the anarchy and folly of sexual desire by having two of Margaret's suitors destroy each other, as well as by having Edward change costumes for a time with the Fool. Similarly, the Margaret-Lacy union recommends the harmonious breakdown of traditional class and rank barriers. But Edward's happy acceptance of an arranged marriage assures the audience that the courtly, aristocratic hierarchy, despite the welcome intrusion of the pastoral world, has remained intact. And although it is the heroine's sexual powers-both of resistance and of surrender - that have brought about these congenial conditions, she nevertheless acknowledges her subordination at the end of the play in a speech of joyfully grateful obedience. The private claims of individual personality and desire have been asserted, recognized, and assimilated into a public vision of social harmony.

Northrop Frye has remarked that "the presiding genius of comedy is Eros, and Eros has to adapt himself to the moral facts of society." 49 As we have seen, Lyly's polarized attitude toward eros as either deviant or ideal makes such an adjustment impossible. Greene takes romantic comedy a step further by working both with Lyly's perspective and with a different set of moral terms, one in which sexual love gains legitimacy as the true source of a coherent society. Although many elements in Friar Bacon remain chaotic and virtually unassimilable, the love story does give the play a distinct shape; therefore it moves significantly toward the vision of inclusiveness symbolized in marriage that is the crowning achievement of Elizabethan comedy. The movement from Lyly to

49. Frye, Anatomy of Criticism, p. I8 I. 


\section{Conceptions of Sexual Love in Elizabethan Comedy}

Greene thus constitutes a development from a view of sexual love as abstract and impersonal, polarized, static, emotionally simple, and morally predictable to another vision that, while retaining much of the skepticism of the first perspective, incorporates it into a view of eros as more concrete, individualized, dynamic and suspenseful, essentially creative, and morally and emotionally complex.

It was by his unique ability both to discern and to express this movement that Shakespeare brought romantic comedy to fruition. The early comedy Love's Labor's Lost (I594-95) can be read in this light as a self-conscious comment on what Shakespeare perceived to be the structurally inevitable relationship between sexual values and the comic form. Love's Labor's Lost begins with the youthful King of Navarre and three lords swearing to retire from social life for three years, declaring war against their "own affections / And the huge army of the world's desires" (I.I.9-I0)..$^{50}$ The absurdity of this oath, which is broken immediately when four eligible young ladies appear, is in part a revelation of the absurdity of sexual desire itself, with its imperious, mechanical urgency. But more important than the silliness of the vow of celibacy is its unnaturalness and futility. "The sea will ebb and flow, heaven show his face: / Young blood doth not obey an old decree" (4.3.2II-I2), states Berowne, the wittiest of the young lords, at the moment of the play when self-knowledge begins. The rejection of celibacy, however, is not enough; the King, Berowne, and company also must learn the meaning of eros as both a civilizing force and a force that must be civilized. Shakespeare conveys their sophomoric callowness as an infatuation with verbal wit, an enchantment with their own cleverness. Upon deciding to pursue his heart's desire, Berowne immediately begins to posture and attitudinize in the conventional courtly manner of a Petrarchan lover, the manner that Edward assumes in Friar Bacon. The wit and charm engendered by this pose recall Lyly; as in Lyly, these qualities make up the substance of the play. But Love's Labor's Lost eventually rejects the courtly love syndrome as sterile, shallow,

50. All quotations, identified in the text by act, scene, and line numbers, are from William Shakespeare, Love's Labor's Lost, ed. Alfred Harbage (Baltimore, Md.: Penguin, I973). 


\section{The Expense of Spirit}

and static. Love conceived as a frivolous game is simply inadequate: when the men approach the women in ridiculous disguises, the women see through them at once. Sensing that the men are not quite ready for grown-up reality, which in Elizabethan comedy means married love, the women, true to romance tradition, demand a year of separation complete with appointed tasks for their lovers before marriage can take place. The play therefore ends with the promise of marriage and not the actuality; the exchange of overblown rhetoric and narcissistic posturing for a plain style and shared experience has not yet come to pass. Consequently, the profound emotional and psychological demands of the comic form have not been completely met, a fact acknowledged directly in a brief conversation between Berowne and the King. Berowne grumbles:

Our wooing doth not end like an old play; Jack hath not Jill. These ladies' courtesy

Might well have made our sport a comedy.

King. Come, sir, it wants a twelvemonth and a day

And then 'twill end.

Ber. That's too long for a play.

$$
\text { [5.2.864-68] }
$$

Shakespeare is announcing clearly here the structural secret of romantic comedy. This clarification of the relationship between fulfilled sexual desire and the comic form releases his ability to represent love as the complex spiritual, emotional, and psychic force that guarantees the perpetuation of society. What is stated so boldly in Love's Labor's Lost is fully dramatized in the comedies that follow: for example, Love's Labor's Lost concludes with a song celebrating summer and winter and suggesting the alliance among fruitful sexual love, the predictably recurring cycle of the seasons, and the ongoing life of society; in ensuing comedies, like $A$ Midsummer Night's Dream (I 595) and As You Like It (I 599), this seasonal imagery becomes fully integrated into the action and poetry, clarifying the inevitable association between human sexuality and great creating nature.

The King of Castile, a character in Friar Bacon, remarks at one point that "men must have wives and women will be wed" 


\section{Conceptions of Sexual Love in Elizabethan Comedy}

(I2.20). "The world must be / peopled" (2.3.233-34), says Benedick in Much Ado about Nothing (I598), ${ }^{51}$ and there are no possibilities of life to which romantic comedy assigns greater value than these. This dramatic celebration of generative sexuality would not have been possible without the significant increase in the prestige of marriage that, as historians have shown, took place in the Renaissance. The movement out of the forest and back into court that dramatizes the harmonious alliance between sexual and social life characterizes Shakespeare's pastoral comedies and is also evident in Friar Bacon, but it is never completed in a Lyly play. Shakespeare manages to develop Greene's optimism about sexual love and social life while eliminating his crude awkwardness, just as he refines Lyly's skepticism while retaining his grace and sense of design.

When viewed in terms of chronological development, Shakespeare's romantic comedies, like the Puritan marriage tracts, reveal an increasing sense of confidence that sexuality as individual assertion can be organized for society's good. At the same time-and the difference from modern conceptions of romantic love is crucial-sexual desire is never idealized for its own sake, never seen as by itself leading to personal happiness, never conceived as a positive value-as love-apart from marriage or procreation. The anxiety that haunts and humiliates writers of Renaissance sexual discourse is always present in Shakespearean comedy, mocking the hope of unique or ideal love with its distrustful sense of the mechanical impersonality of sex. It is the imperative, arbitrary quality of sexual desire that makes it seem bestial and foolish to the Elizabethans, but in Shakespearean comedy submission to this imperative also joins humanity to nature in fruitful union. Sexuality therefore presents itself as a paradox: the human need for sexual relationships could lead to the mindless disruption of society, but without fulfillment of this need, there would be no ordered society at all.

Shakespeare's rendering of Berowne in Love's Labor's Lost as

5I. All quotations, identified in the text by act, scene, and line numbers, are from William Shakespeare, Much Ado about Nothing, ed. A. R. Humphreys (New York: Methuen, I98I). 


\section{The Expense of Spirit}

commenting with freely conscious knowingness on the absurdity of his own desires reveals an early effort to encompass the paradoxes of sex; but the abstract choreography of the play makes full dramatization of this issue impossible. The dramatic conflict of $A$ Midsummer Night's Dream is, of course, set in motion by the issue of individual choice of a mate versus forced marriage. Although the young lovers triumph over irrational parental opposition to their desires, their victory is suffused with irony. The lovers imagine that they are defiantly asserting their individuality; but the lack of differentiation among them and the mix-up in the forest clarify both their lack of uniqueness and the arbitrary quality of their choices. Demetrius never does know what hit him when he returns to Helena, any more than he ever did when he loved and rejected her in the first place. The arrogance and complacence of both Theseus and the young lovers are further qualified by the final assertion of the irrational, imaginative authority of the fairies; and the absurd, arbitrary, and mysterious nature of sexual desire is distilled in the joyful parody of Bottom's dream. Though the tensions inherent in achieving erotic identity are never resolved, the suggestion in A Midsummer Night's Dream is that harmony is attained by the intervention of a benevolent, reconciliatory Providence, which manifests itself on the social level in the final wedding feast.

As Arthur Kirsch has shown in his analysis of Much Ado About Nothing, the tensions between freedom of choice and submission to authority are not entirely imposed from without, but are rooted psychologically in sexuality itself. ${ }^{52}$ Claudio and Hero never acknowledge these internal tensions between the immediate demands of their desires and their deeper fears of surrender and rejection in love. They become engaged thoughtlessly, following the conventional clichés of society while never imagining the complex, mixed nature of sexual love; as a result of their psychological and emotional oblivion, they remain completely vulnerable to doubt and fear. Claudio and Hero are contrasted to the witty Beatrice and Benedick, who, more thoughtful and consequently more wary of love's complications and paradoxes, pride themselves on their independence. But this brilliant couple needs the manipula-

52. Arthur Kirsch, Shakespeare and the Experience of Love (Cambridge: Cambridge University Press, 198I), pp. 40-70. 


\section{Conceptions of Sexual Love in Elizabethan Comedy}

tive, busybody society of Much Ado to liberate them from the lonely trap of their uniqueness. Released from their fears, they are free to join society by loving one another. Benedick and Beatrice are one of the first outstanding pairs of lovers in Shakespeare, the first to command complete sympathy because of their personalities. "Man is a giddy thing and this is my conclusion" (5.4. 107), Benedick announces at the end of Much Ado, revealing that the paradoxical awareness of sexual desire, enjoyed by the audience of A Midsummer Night's Dream with a kind of superior irony, is appropriated in Much Ado by Benedick and Beatrice themselves, who are humbly aware that in seeming to lose their identities, they have in fact gained self-knowledge. In the sense of gratitude for life that is consequently released in them, Shakespeare exhibits the same awareness of the joyful mysteries of sexual love that he always portrays. But I believe that in individualizing Benedick and Beatrice to the extent that he has, and in allowing them to achieve selfknowledge, he reveals an enhanced respect for the human dignity of sexual life as well. 53

As I have tried to show in discussing the Puritan marriage tracts, the increasing moral prestige of love and marriage in the Renaissance was accompanied by a wider acknowledgment of the social, emotional, and spiritual dignity of women, whose freedoms of action and influence were nevertheless explicitly and severely limited. Developing an insight latent in Greene, Shakespeare seems to have assimilated these paradoxical facts imaginatively by giving women the heroic roles in many of his major comedies; their heroism consists, however, in choosing to preserve the status quo by wisely and lovingly assimilating themselves to it. Rosalind in $A s$ You Like It is the supreme romantic comic heroine. ${ }^{54}$ With her realism, openness, and depth, she seems blessed with self-knowl-

53. Cf. R. A. Foakes, "The Owl and the Cuckoo: Voices of Maturity in Shakespeare's Comedies," in Shakespearean Comedy, Stratford-upon-Avon Studies, no. I4, ed. J. R. Brown and B. Harris (London: Edward Arnold, I972), p. I32; and B. K. Lewalski, "Love, Appearance and Reality: Much Ado about Something," Studies in English Literature, 8 (1968), 243. For an opposite view of Beatrice and Benedick, see A. P. Rossiter, "Much Ado about Nothing," in Shakespeare: The Comedies, ed. Kenneth Muir (Englewood Cliffs, N.J.: Prentice-Hall, I965), p. 5 I.

54. Cf. Clara Claiborne Park, “As We Like It: How a Girl Can Be Smart 


\section{The Expense of Spirit}

edge from the beginning, superbly adapted to exploit successfully the ironies of experience and desire. The mastery of her erotic quest is epitomized in her education of Orlando, in whom she instills a knowledge of the demands of love for a real woman in actual life that allows him to grow beyond the shallow, remote conventionalities of the Petrarchan lover. ${ }^{55}$ The extent to which Rosalind's individuality remains in complete spiritual harmony with nature becomes apparent in the way she controls the timely release of erotic energy embodied in the array of marriages at the end of the play. Just as the negative components of sexual desire are largely displaced onto Claudio and Hero in Much Ado, so the other couples in the procession at the end of As You Like It suggest the less attractive aspects of sexuality, leaving the Rosalind-Orlando union relatively free of ironic qualification. The fact that Rosalind finds the freedom to accomplish all that she does while disguised as a boy and then sheds this disguise at the end of the play again brings to mind the insoluble contradictions of the female condition, much as these contradictions present themselves in the Puritan marriage tracts. But Shakespeare emphasizes reconciliation, not contradiction; nothing like the sentimental, didactic surrender of Margaret in Friar Bacon mars the predominant (and intended) feeling of harmony at the end of As You Like It. If the audience is meant to be reminded of any paradox about the loving surrender of individual identity to society, it is the Christian one of losing in order to gain, dying in order to live.

That the potentially contradictory functions of Rosalind's disguise should be reconciled symbolically in marriage clarifies the idea that the erotic teleology of Elizabethan comedy demands an "imaginative model of desire" based on the harmonious resolution of sexual conflict. Given his skeptical, polarized view of sexual love, Lyly could not make the desired reconciliation demanded by the wish-fulfillment pattern at the heart of the comic form. Greene discerned the need to harmonize both the anarchic and the civiliz-

and Still Popular," in The Woman's Part, ed. Carolyn Ruth Swift Lenz, Gayle Greene, and Carol Thomas Neely (Urbana: University of Illinois Press, I980), pp. IO0-I I6.

55. Cf. Kent Talbot Van Berg, "Theatrical Fiction and the Reality of Love in As You Like It," PMLA, 90 (October 1975), 885-93. 


\section{Conceptions of Sexual Love in Elizabethan Comedy}

ing components of sexual desire into a vision of social and spiritual harmony. But it was Shakespeare who perfected this vision, drawing out all its implications with neither awkwardness nor sentimentality. The witty vitality with which Shakespeare endows the lovers in Much Ado and As You Like It contributes to an enhanced sense of their individuality and self-knowledge; since the imperative, urgent impersonality of sexual desire was what made it seem both dangerous and ridiculous to the Elizabethans, these more distinctive characterizations consequently suggest a greater respect for the human dignity of sexual experience. But comedy cannot accommodate too much individuality, any more than it can lose its sense of the ridiculous. As is well known, comedy focuses not on the destiny of the individual, which ends in death, but on the destiny of human society as a whole, which is perpetual. ${ }^{56}$ Interestingly, in his last romantic comedy, Twelfth Night (I600), the play in which Shakespeare completely masters and exhausts the possibilities of this form of drama, he focuses less on the selfknowledge of the characters and more on the intervention of a benevolent Providence in sorting out human affairs satisfactorily. ${ }^{57}$ On the one hand, the idea of a benevolent Providence assisting human destiny illuminates all of his romantic comedies; on the other, the lovers in Twelfth Night are distinctly more individualized than those in Love's Labor's Lost or A Midsummer Night's Dream. But it is a question of emphasis and degree.

Elizabethan romantic comedy was able to achieve its aim-the representation of a harmonious, spiritually integrated society symbolized in marriage-in a cultural environment in which love and

56. See Gardner, pp. 193-94.

57. Cf. Leo Salingar, Shakespeare and the Traditions of Comedy (Cambridge: Cambridge University Press, I974), pp. 240-42. Salingar believes that "Twelfth Night is the summing-up of a major phase in Shakespeare's writing, the last romantic play at the end of a decade, because it deals with the psychological value of revelry and its limits as well; it is a comedy about comedy.... As the play advances, psychological mistakes dissolve into 'errors' of identity; Time and Nature, assuming the guise of Fortune, are stronger than characters' 'reason,' their conscious will. Although the actors have been given some of the depth and self-awareness of individuals in real life, they are caught up in a situation that evidently belongs less and less to real life and increasingly to the stage." 
marriage were gaining moral prestige and, as a corollary, personal happiness and freedom began to be considered goals worth pursuing. Currently a debate has arisen about whether Puritan marriage ideology, which, like Rosalind's disguise in As You Like It, enhanced female dignity and autonomy while at the same time explicitly reinforcing the double standard, has positive or negative effects for women. ${ }^{58}$ The important point here is the clear correspondence between the potentially contradictory view of sexual values presented in the Puritan tracts and the representation of sexual tensions in Elizabethan comedy. In both forms we can see certain conceptual antitheses beginning to take shape: personal freedom and social convention, happiness and stability, civilization and its discontents. But neither the theologians nor the comic playwrights drew final attention to the conflicts implicit in their conceptions of erotic love and marriage. As we will see in the discussion of tragedy (Chapter 3), the Puritan preachers simply did not perceive the inherent contradictions in their sexual values. Although the playwrights discerned the outlines of comic structure in the drama of sexual desire seeking and finding satisfaction, they represented potentially conflicting social and erotic forces mainly in order to reconcile them. In Shakespearean comedy happiness and stability are the same.

Keith Thomas has linked the preponderance of sexual humor in Tudor and Stuart England to a pervasive anxiety about changing sexual relationships. Thomas recognizes that among its many functions, comedy can perform the conservative one of introducing potentially disruptive elements only to represent them as harmoniously assimilated within the existing social structure. ${ }^{59}$ As the implications of the idealization of marriage and the claims of the individual self became more pressing, conflicts that were evoked but contained in one form of drama became grist for the mill of other forms. In Jacobean England love and sexuality began to be subjected to the savage scrutiny of satire and tragedy.

58. See Fitz; and Juliet Dusinberre, Shakespeare and the Nature of Women (London: Macmillan, 1975).

59. Keith Thomas, "The Place of Laughter in Tudor and Stuart England," Times Literary Supplement, 2 I January I977, pp. 77-8I. Also see Mary Douglas, "The Social Control of Cognition: Some Factors in Joke Perception," Man, 3 (September I 968), 36I-76. 